\title{
Assessment of knowledge and skills of patients with hypertension related to self-measurement of blood pressure (SBPM)
}

\author{
Justyna Dymek, Agnieszka Skowron, Wioletta Polak, Anna Gołda \\ Department of Social Pharmacy, Faculty of Pharmacy, Jagiellonian University Medical College
}

\begin{abstract}
Summary
Background Scientific societies have provided massive guidance on the role blood pressure self-measurements play in assessing hypertension treatment effectiveness, where the necessity for the measurements to strictly follow manual and general instructions in order to obtain proper and reliable readings have been underlined and highlighted.

Material and methods The present study has been aimed at assessing knowledge and skills regarding blood pressure self-measurements by hypertension patients. The patients self-monitored their blood pressure twice a day with a RossmaxAI95CA sphygmomanometer for 10 days. The videorecorded measurements were analysed and the patients' skills were marked independently by 2 researchers with regard to 20 parameters. A 10 question test was applied to rank each patient's knowledge. The study was performed at community pharmacies and a health centre in Malopolska region. Results The study involved 14 patients. A score of 4 points was found to be the mean test score. Less than $30 \%$ of the respondents answered properly the questions on cuff inflation value, time interval between having a coffee and taking the measurement to be respected, or which arm to select for measurements. A mean score for measurement performance skills, based on the video analysis, reached 12.2 points, which corresponds to $61 \%$ compliance. The patients tended to take blood pressure measurements while leaning forward, as they sat too far from the table, thus having their arm not supported properly. The cuff placed too low, i.e. at the bend of the elbow, or set inversely, with the air tube up, proved to be the most common mistakes. While taking measurements patients would adjust their position in the chair, re-inflate the cuff, write, or inflate the cuff with the hand on which it was placed.

Conclusions The study has shown that hypertension patients due to their insufficient skills and limited knowledge shall be subjected to proper educational procedures on blood pressure self-measurements.

key words: blood pressure measurementl, self-monitoring, measurement error, self blood pressure monitor, SBPM, medical education, hypertension
\end{abstract}

Arterial Hypertension 2015, vol. 19, no 1, pages: 39-44

DOI: $10.5603 / A H .2015 .0007$

\section{Background}

Self blood pressure monitoring (SBPM) plays a vital role in hypertension treatment as it allows to evaluate the treatment effectiveness. It has been high- lighted in guidance given by both Polish and foreign scientific societies for hypertension and cardiologic disorders [1-5]. Regular blood pressure monitoring helps to build a comprehensive picture of the disease and to evaluate how effective the adopted treatment

Address for correspondence: Justyna Dymek MSc, The Department of Social Pharmacy

Faculty of Pharmacy, Jagiellonian University Medical College

Medyczna 9 Street, 30-688 Kraków, e-mail: jdymek@cm-uj.krakow.pl

V M Copyright (C 2015 Via Medica, ISSN 2449-6170

Supporting institution: Jagiellonian University Medical College — targeted subsidy for the professional development of young scientists K/DSC/000802 
is, both pharmacological and non-pharmacological. Supported with individual measurements diaries it makes alert blood pressure situations, potentially hazardous for the patient's health, recognisable and manageable. In contrast to measurements taken at medical settings, blood pressures recorded at home and self-measurements, i.e. SBPM, tend to differ and be closer to mean values obtained during ABPM taken over $24 \mathrm{~h}$ monitoring. Home measurements allow determining whether the observed hypertension is white-coat related or masked hypertension [6,7]. They also give more reliable readings for individual patients [8].

Thus, a SBPM outcome provides important data for controlling patient's overall health condition, provided the data is obtained properly and in accordance with guidance given by scientific societies, as both accuracy and reliability of readings can be affected by a number of factors [1-5]. The guidance provide a detailed set of rules for recording reliable blood pressure readings, including in particular:

- proper body posture while taking the measurement;

- the necessity of selecting the arm for taking measurements;

- time lapse following meals;

- time lapse following coffee;

- time interval between having a cigarette and taking a measurement;

- cuff size;

- proper cuff setting;

- general behaviour rules for the patient, including manual inflating the cuff with the hand of the other arm (with no cuff on), keeping quiet and still, recording the readings and other circumstances in the patient's diary, environmental conditions at the time of measurement such as noise, temperature etc. [1-5, 9].

Additionally, the study proved the specific type of applied measuring device to impact the readings reliability. Neither mercury, aneroid, nor automatic wrist sphygmomanometers are recommended for blood pressure self-measurements $[9,10]$.

As mentioned before, proper performance of blood pressure measurement remains crucial. Unfortunately, patients are hardly familiar with the proper measurements performance rules that shall be additionally coupled with practical knowledge and skills applied to specific type of the measuring device they use $[11,12]$. Many reported studies confirm that technical incompatibilities in measuring blood pressure, along with shortcomings in interpreting reading skills, have prevented the results from being clinically viable due to their unreliability $[13,14]$.

\section{Materials and methods}

The aim of the study was to assess knowledge and skills at performing measurements by hypertensive patients who monitor their own blood pressure (SBPM).

The study involved 18 hypertension diagnosed patients. For the reasons unrelated to the patients and the researcher, only 14 patients were subjected to the study carried out in community pharmacies and a health centre in Malopolska region. Each patient was provided with an upper arm, semi-automatic sphygmomanometer, namely Rossmax AI95CA, with which over 10 days they double-measured their own blood pressure twice a day, and recorded the readings in their diaries. Each measurement was video-recorded with an internet camera.

Patients' knowledge was assessed with a test on carrying blood pressure measurements and interpreting the measurement results; the test was taken prior to the study. A qualitative analysis was performed on 508 video recordings from blood pressure self-measurements carried out by the patients. Their performance was marked by two independent researchers. A set of performance parameters, defined by scientific societies guidance as crucial to make a reliable measurement, was considered. The third video examination was applied whenever the researchers failed to reach agreement on any parameter. Overall number of 20 parameters was examined, each scoring 1 point; the test covered 10 questions.

\section{Results}

Fourteen patients, aged from 29 to 86 years, participated in the study. The patients of various educational background had been previously diagnosed with hypertension, with time sequence between over half a year to 32 years. Six of the patients did not have a sphygmomanometer at home, five used to apply wrist sphygmomanometers, and only one of them was in the possession of an upper-arm, semi-automatic device, recommended in the guidelines by scientific societies.

Three patients declared no SBPM skills, as they were not in the possession of any sphygmomanometer. The group included the hypertension patient diagnosed 32 years ago. Two other hypertension patients with no sphygmomanometer used to measure their blood pressure in a community pharmacy. $\mathrm{Pa}$ tients who had sphygmomanometers fail to meet the recommended number of daily measurements. Only one patient declared taking a few measurements 
Table I. Participants profiles and their SBPM parameters

\begin{tabular}{|c|c|c|c|c|c|c|c|c|c|}
\hline & Gender* & Age & $\begin{array}{c}\text { Education } \\
\text { level }\end{array}$ & $\begin{array}{c}\text { Time } \\
\text { lapse from } \\
\text { diagnosis } \\
\text { (in years) }\end{array}$ & $\begin{array}{c}\text { Blood } \\
\text { pressure } \\
\text { monitor } \\
\text { at home* }\end{array}$ & $\begin{array}{l}\text { Sphygmo- } \\
\text { manometer } \\
\text { type }\end{array}$ & $\begin{array}{l}\text { SBPM skills } \\
\text { subjective } \\
\text { assessment }\end{array}$ & SBPM* & SBPM frequency \\
\hline Patient 1 & W & 86 & Secondary & 1 & + & Wrist & + & + & Once a day \\
\hline Patient 2 & W & 65 & Secondary & 2 & - & - & + & $\begin{array}{c}+ \\
\text { (in pharmacy) }\end{array}$ & A few times a week \\
\hline Patient 5 & W & 71 & Primary & 10 & + & Wrist & + & + & When feeling unwell \\
\hline Patient 6 & W & 49 & University & 8 & - & - & - & - & Not measured \\
\hline Patient 7 & W & 29 & University & 0.5 & - & - & + & $\begin{array}{c}+ \\
\text { (at family) }\end{array}$ & Not measured \\
\hline Patient 9 & M & 46 & Secondary & 8 & + & Wrist & + & + & When feeling unwell \\
\hline Patient 10 & W & 73 & Primary & 5 & + & $\begin{array}{l}\text { Upper arm semi } \\
\text { automatic }\end{array}$ & + & + & When feeling unwell \\
\hline Patient 11 & M & 56 & Secondary & 32 & - & - & - & - & Not measured \\
\hline Patient 12 & W & 69 & Primary & 4 & + & $\begin{array}{l}\text { Mercury and } \\
\text { wrist }\end{array}$ & + & + & Not measured \\
\hline Patient 13 & W & 43 & Secondary & 2 & + & Aneroid & + & + & When feeling unwell \\
\hline Patient 14 & W & 52 & Secondary & 6 & - & - & - & - & $\begin{array}{l}\text { When feeling unwell } \\
\text { (at the clinic) }\end{array}$ \\
\hline Patient 15 & W & 45 & Secondary & 7 & + & Mercury & + & - & $\begin{array}{l}\text { When feeling unwell } \\
\text { (with family as- } \\
\text { sistance) }\end{array}$ \\
\hline Patient 17 & W & 67 & University & 1 & - & - & + & $\begin{array}{l}+ \\
\text { (in pharma- } \\
\text { cy) }\end{array}$ & Once a day \\
\hline Patient 18 & W & 77 & Secondary & 10 & + & Wrist & + & + & Several times a day \\
\hline
\end{tabular}

${ }^{*} \mathrm{~W}$ - women, $\mathrm{M}-$ men, + yes, - no

a day, regretfully with a wrist sphygmomanometer (not recommended device). Table I covers the detailed patients' data.

In the test on proper blood pressure measurement performance and interpreting the obtained readings, where 10 was the maximum score, an average score of 4 was achieved (2-6). Patients managed to answer 56 out of 140 queries, achieving $40 \%$ correctness. Patients of university, secondary and primary education scored an average of 5.7, 3.9, and 2.7, respectively. Patients with no sphygmomanometer at home scored a higher average (see Table II).

The number of correct answers to specific test questions was analysed. Only 2 patients managed to provide the recommended daily measurements frequency for a hypertension sufferer, and the time lapse to be respected after a full meal to take the measurement. The patients were most knowledgeable about the required body posture while taking measurements. The question was answered correctly by 12 patients (Table III).

A percentage of correct answers to test queries for individual patients were compared with their knowledge assessed subjectively. As many as 8 patients assessed their knowledge higher than the actual test score proved it to be. The highest divergence was found for 3 patients, whose knowledge proved to be $50 \%$ lower when related to their subjective mark. Subjective mark of one patient happened to fall lower than his test score $(20 \%$ vs $60 \%)$. Five patients ranked their knowledge in line with their test result. See Table IV for details.

The average number of points scored per patient with respect to measurement performance, based on the video recording analysis, reached 12.2, with 20 
Table II. Distribution of average test score

\begin{tabular}{|c|c|c|c|}
\hline & & $\mathbf{N}$ & $\mathrm{n} \pm \mathrm{SD}(\min -\max )$ \\
\hline \multicolumn{2}{|l|}{ Total } & 14 & $\begin{array}{c}4.0 \pm 1.4 \\
(2-6)\end{array}$ \\
\hline \multirow[t]{2}{*}{ Gender } & Female & 12 & $\begin{array}{c}4.0 \pm 1.5 \\
(2-6)\end{array}$ \\
\hline & Male & 2 & $\begin{array}{c}4.0 \pm 0.0 \\
(4-4)\end{array}$ \\
\hline \multirow[t]{3}{*}{ Education } & Primary & 3 & $\begin{array}{c}2.7 \pm 1.1 \\
(2-4)\end{array}$ \\
\hline & Secondary & 8 & $\begin{array}{c}3.9 \pm 1.0 \\
(2-5)\end{array}$ \\
\hline & University & 3 & $\begin{array}{c}5.7 \pm 0.6 \\
(5-6)\end{array}$ \\
\hline \multirow{5}{*}{$\begin{array}{l}\text { Subjective } \\
\text { assessment of } \\
\text { knowledge (1-5) }\end{array}$} & 1 & 1 & $\begin{array}{c}6.0 \\
(6-6)\end{array}$ \\
\hline & 2 & 5 & $\begin{array}{c}3.6 \pm 0.9 \\
(2-4)\end{array}$ \\
\hline & 3 & 3 & $\begin{array}{c}5.0 \pm 1.0 \\
(4-6)\end{array}$ \\
\hline & 4 & 5 & $\begin{array}{c}3.4 \pm 1.5 \\
(2-5)\end{array}$ \\
\hline & 5 & 0 & - \\
\hline \multirow[t]{2}{*}{$\begin{array}{l}\text { Blood pressure } \\
\text { monitor }\end{array}$} & Yes & 8 & $\begin{array}{c}3.2 \pm 1.5 \\
(2-5)\end{array}$ \\
\hline & No & 6 & $\begin{array}{c}4.5 \pm 1.2 \\
(4-6)\end{array}$ \\
\hline
\end{tabular}

Table III. Correct answers distribution for specific questions

\begin{tabular}{l|c|c}
\hline & \multicolumn{3}{c}{$\begin{array}{c}\text { Correct } \\
\text { answers } \\
\text { (N = 14) }\end{array}$} \\
\hline & n & $\%$ \\
\hline $\begin{array}{l}\text { Recommended frequency of daily measurement } \\
\text { Hearty meal — SMBP minimum interval }\end{array}$ & 2 & 14.3 \\
\hline The value for inflating the cuff & & \\
\hline $\begin{array}{l}\text { Coffee — SMBP minimum interval } \\
\text { Arm selection for measurements }\end{array}$ & 3 & 21.4 \\
\hline $\begin{array}{l}\text { Time lapse between two consecutive } \\
\text { measurements }\end{array}$ & 4 & 28.6 \\
Factors impacting readings & 5 & 35.7 \\
\hline $\begin{array}{l}\text { Requested medicine administration time lapse prior } \\
\text { to SMBP }\end{array}$ & 8 & 57.1 \\
\hline Pressure indicating hypertension & & \\
\hline Body posture during measurement & 11 & 78.6 \\
\hline & 12 & 85.7 \\
\hline
\end{tabular}

maximum to score, i.e. $61 \%$ compliance with the requirements. Details on the specific elements performance are presented in Table $\mathrm{V}$.
Due to overrated table-patient distance while performing measurements the patients leaned forward, with their back unsupported and with no proper support for their arm. Equally frequent arm related mistakes were keeping it tightly held against the trunk, or taking measurement with the clench fist turned downward. Over $80 \%$ recordings revealed that patients have failed to rest both prior to the first and the following measurements.

The most frequent cuff related errors included placing it too low, i.e. at the elbow joint, or reversed (with the air tube up). Patients found it also troublesome to properly position the air tube itself, which was not set at the inner side of the elbow bent. While measuring their blood pressure patients tended to adjust their position in the chair, routinely re-inflate the cuff, or take notes. The cuff was found also to be inflated with the hand of the same arm on which it was set. Two patients took measurements on the arm with not higher pressure.

Patient's knowledge determined by the test score were compared with their skills assessed on the base of video recordings of their blood pressure self-measurements (see Table IV). In general patients scored higher percentage in skills than in the test. For three patients the difference reached as high as $40 \%$, one patient's knowledge levelled his practical skills, while for the other 4 these parameters differed by $10 \%$.

The average scores for practical SBPM skills were compared for the patients who declared themselves as skilled prior to participating in the study, as well as for those who declared no skills. None differences were found for any of these groups, $61.8 \%$ vs $60.8 \%$. For two patients skilled by declaration, their SBPM score was lower than $50 \%$ of the maximum attainable score. The highest average reached 78\% compliance for performing the blood pressure measurements (see Table IV).

\section{Discussion}

The study was carried out by a research pharmacist at community pharmacies and at a heath care centre; the measurements were performed at comfortable, discreet settings, compliant with all the requirements recommended by scientific societies. Local pharmacists and physicians were involved in the campaign to inform patients and distribute promotional leaflets addressed to them.

The obtained results show that patients fail to check their blood pressure at home regularly. Among 14 hypertension sufferers involved in the study, 4 patients declared no measurements at all, 
Table IV. Subjective assessment of knowledge versus test score and SBPM skills for individual patients

\begin{tabular}{l|c|c|c|c|c|c|c}
\hline & \multicolumn{2}{c}{ Subjective assessment of knowledge (1-5) } & \multicolumn{2}{c}{ Average test score (0-10) } & \multicolumn{2}{c}{ Average skills score (0-20) } \\
\cline { 2 - 9 } & \multicolumn{2}{c}{ N } & \multicolumn{2}{c}{$\%$} & \multicolumn{2}{c}{ N } & \multicolumn{2}{c}{ \% } \\
\hline Patient 1 & 4 & 80.0 & Yes & 2 & 20.0 & 14.3 & 71.5 \\
\hline Patient 2 & 4 & 80.0 & Yes & 5 & 50.0 & 15.6 & 78.0 \\
\hline Patient 5 & 2 & 40.0 & Yes & 4 & 40.0 & 9.2 & 46.0 \\
\hline Patient 6 & 3 & 60.0 & No & 6 & 60.0 & 11.9 & 59.5 \\
\hline Patient 7 & 1 & 20.0 & Yes & 6 & 60.0 & 10.4 & 52.0 \\
\hline Patient 9 & 3 & 60.0 & Yes & 4 & 40.0 & 12.8 & 64.0 \\
\hline Patient 10 & 2 & 40.0 & Yes & 2 & 20.0 & 11.4 & 57.0 \\
\hline Patient 11 & 2 & 40.0 & No & 4 & 40.0 & 13.3 & 66.5 \\
\hline Patient 12 & 4 & 80.0 & Yes & 2 & 20.0 & 12.2 & 61.0 \\
\hline Patient 13 & 4 & 80.0 & Yes & 5 & 50.0 & 11.7 & 58.5 \\
\hline Patient 14 & 2 & 40.0 & No & 4 & 40.0 & 11.9 & 59.5 \\
\hline Patient 15 & 2 & 40.0 & Yes & 4 & 40.0 & 9.7 & 48.5 \\
\hline Patient 17 & 3 & 60.0 & Yes & 5 & 50.0 & 13.6 & 68.0 \\
\hline Patient 18 & 4 & 80.0 & Yes & 3 & 30.0 & 12.8 & 64.0 \\
\hline Average & $\mathbf{2 . 8}$ & $\mathbf{5 6 . 0}$ & - & 4.00 & 40.0 & $\mathbf{1 2 . 2}$ & $\mathbf{6 1 . 0}$ \\
\hline
\end{tabular}

Table V. Percentage of guidance compliant SBPM (parameters observed)

\begin{tabular}{l|c|c}
\hline Assessed parameters, $\mathbf{N}=\mathbf{2 0}$ & \multicolumn{2}{c}{$\begin{array}{c}\text { Videos where } \\
\text { parameters } \\
\text { were observed } \\
\text { (N = 508) }\end{array}$} \\
\cline { 2 - 3 } & $\mathbf{n}$ & $\%$ \\
\hline The distance from the table & 5 & 1.0 \\
\hline Back against the chair & 18 & 3.5 \\
\hline Rest prior to SMBP & 97 & 19.1 \\
\hline No comments on the cuff setting (height, direction) & 110 & 21.6 \\
\hline Sitting straight (upright posture) & 167 & 32.9 \\
\hline Facing the table & 184 & 36.2 \\
\hline Hand position (up) & 224 & 44.1 \\
\hline Arm rested properly & 308 & 60.6 \\
\hline Air tube in the middle of the elbow joint & 312 & 61.4 \\
\hline No hand/arm movement (with the cuff) & 339 & 66.7 \\
\hline Hand open & 355 & 69.9 \\
\hline Air tube on the elbow joint inner side & 358 & 70.5 \\
\hline None excessive activities & 402 & 79.1 \\
\hline Tight-sleeved clothing removed from the arm & 406 & 79.9 \\
\hline Successful at the first attempt & 455 & 89.6 \\
\hline No conversations & 465 & 91.5 \\
\hline SMBP reading recorded in the diary & 501 & 98.6 \\
\hline No legs movement & 503 & 99.0 \\
\hline Selected arm rested free on a table & 508 & 100.0 \\
\hline Sitting posture & 508 & 100.0 \\
\hline
\end{tabular}

while 6 reported measuring their blood pressure only when felling unwell. Similar data were collected by Szczęch, who examined other Polish population. It shown that the fraction of hypertension sufferers who failed to take any blood pressure measurements, including check-ups at their physicians, over a year preceding the study, reached $20 \%$ in women and $33 \%$ in men [11]. Percentage as high as $63 \%$ of the overall population of hypertension sufferers was reported by Skowron to fail to perform their blood pressure measurements regularly, on a daily basis. Nevertheless, the same study found $90 \%$ of the respondents to admit that regular self-monitoring of their blood pressure is necessary [12].

The patients participating in the study did not possess monitors recommended by the scientific societies. Similarly to the study by Williński made in 2007, we found that patients still use mercury, aneroid, or wrist sphygmomanometers, whose readings are not reliable enough. In addition, neither mercury nor aneroid sphygmomanometers store the readings, which implies that SBPM readings evaluation, based solely on diary records made by patients, may be burdened with further unreliability $[10,15-17]$.

The results proved that medical staff while assessing patients knowledge on the subject cannot rely on their subjective ratings on the related knowledge or SBPM skills. More than $50 \%$ of patients overestimated 
their SBPM knowledge. Within the group of patients declaring themselves as skilled, were patients whose average score, based on the video-recorded sessions, fell below $50 \%$.

The patients diagnosed with hypertension participating in the study demonstrated neither sufficient knowledge, nor skills related to self-monitoring their own blood pressure (SBPM), or interpreting the readings. Hypertension sufferers scarcely knowledge about their illnesses, monitoring their heath condition, as well as proper lifestyle and diet, were also reported by the study carried out in Poland in 2007. The questions testing patients' knowledge on monitoring blood pressure and interpreting the readings were found by the patients to be the most troublesome. The average score was 2.2 at 5 as a maximum score [12].

The presented study, aimed at detailed testing solely patients' familiarity on performing blood pressure self-measurements, showed the patients to score on average $40 \%$, whereas their practical skills were scored as $61 \%$ compliant with the guidelines. The patients took self-measurements regularly, at set times, twice a day over a period of 10 days. It produced 508 video recorded sessions. The analysed videos revealed that patients rested neither prior to the first measurement, nor further ones. Frequently, the measurements were performed right after entering the room. Regular mistakes such as setting the cuff too low, clenching the fists, or adjusting postures during measurements are reported to have impact on the recorded readings. Similarly observed mistakes such as arms not rested on the table, backs not backed against the chair, or arms hold tight to the corpse, may affect the reliability of the readings $[9,14]$.

It can be concluded from the presented study that good practice for blood pressure self-monitoring in hypertension patients has not been widespread, and patients' SBPM attempts cannot be considered fully reliable not only due to their scarce knowledge on the subject and low skills, but also due to the monitors they use, which are neither recommended, nor validated. Prior to practical implementation of self-monitoring blood pressure by the patients that guarantees recording reliable results, the patients should be educated how to compliantly perform blood pressure measurements by themselves, and presented with information on the recommended sphygmomanometers to apply.

\section{Conclusions}

The evaluation of SBPM-related knowledge and skills in patients' needs to be verified with proper and professional assessment tools. As the patients obliged to perform SBPM were found neither knowledge, nor skilled enough, education procedures on self-monitoring need to be implemented for them.

\section{Referencess}

1. Mancia G., De Backer G., Dominiczak A. et al. 2007 ESH-ESC Practice Guidelines for the Management of Arterial Hypertension. J. Hypertens. 2007; 25: 1751-1762.

2. Widecka K., Grodzicki T., Narkiewicz K. et al. Zasady postępowania w nadciśnieniu tętniczym - 2011 rok. Wytyczne Polskiego Towarzystwa Nadciśnienia Tętniczego. Nadciśnienie Tętnicze 2011; 15: 55-82.

3. Mancia G., Fagard R., Narkiewicz K. et al. 2013 ESH/ESC Guidelines for the management of arterial hypertension: the Task Force for the management of arterial hypertension of the European Society of Hypertension (ESH) and of the European Society of Cardiology (ESC). J. Hypertens. 2013; 31: 1281-1357.

4. National Heart, Lung, and Blood Institute (US). The Seventh Report of the Joint National Committee on Prevention, Detection, Evaluation, and Treatment of High Blood Pressure (JNC7). NIH Publication No. 04-5230, 2004.

5. James P.A., Oparil S., Carter B.L. et al. 2014 Evidence-Based Guideline for the Management of High Blood Pressure in Adults Report From the Panel Members Appointed to the Eighth Joint National Committee (JNC 8). JAMA 2014; 311: 507-520.

6. Celis H., Fagart R.H. White-coat hypertension: a clinical review. Eur. J. Intern. Med. 2004; 15: 348-357.

7. Głuszek J.A., Olszewski W. Nadciśnienie maskowane (ukryte). Uwagi kliniczne. Choroby Serca i Naczyń 2010; 7: 1-6.

8. Czupryniak L., Pawłowski M., Saryusz-Wolska M. Samokontrola ciśnienia tętniczego przez chorego na cukrzycę — korzyści udowodnione czy domniemane? Przew. Lek. 2008; 3: 32-34.

9. Ogedegbe G., Pickering T. Principles and techniques of blood pressure measurement. Cardiol. Clin. 2010; 28: 571-586.

10. Parati G., Asmar R., Stergiou G.S. Self blood pressure monitoring at home by wrist devices: a reliable approach? J. Hypertens. 2002; 20: 573-578.

11. Szczęch R., Bieniaszewski L., Furmański J., Narkiewicz K., Krupa-Wojciechowska B. Ocena częstości, świadomości i skuteczności leczenia nadciśnienia tętniczego wśród uczestników akcji „Mierz ciśnienie raz w roku”. Nadciśnienie Tętnicze 2000; 4: 27-37.

12. Skowron A., Dymek J. Ocena wiedzy pacjentów z nadciśnieniem tętniczym i cukrzycą. Farm. Pol. 2008; 13: 583-589.

13. Marshall T. Blood pressure measurement: the problem and its solution. J. Hum. Hypertens. 2004; 18: 757-759.

14. Logan A.G., Dunai A., McIsaac W.J., Irvine M.J., Tisler A. Attitudes of primary care physicians and their patients about home blood pressure monitoring in Ontario. J. Hypertens. 2008; 26: 446-452

15. Wiliński J., Czarnecka D., Bilo G. et al. Przestrzeganie zasad prawidłowego pomiaru ciśnienia tętniczego przez chorych na nadciśnienie tętnicze w praktyce samodzielnych pomiarów ciśnienia tętniczego (SBPM). Nadciśnienie Tętnicze 2007; 11: 53-59.

16. Rouse A., Marshall T. The extent and implications of sphygmomanometer calibration error in primary care. J. Hum. Hypertens. 2001; 15: 587-591.

17. Jain A., Krakoff L.R. Effect of recorded home blood pressure measurements on the staging of hypertensive patients. Blood Press. Monit. 2002; 7: 157-161. 